\title{
An Ultrastructural Approach for Gill Responses After Pollutants Exposure
}

\author{
Un Enfoque Ultraestructural de las Respuestas Branquiales \\ Después de la Exposición a Contaminantes
}

Bruno Fiorelini Pereira; Dimítrius Leonardo Pitol ${ }^{2}$ \& Flávio Henrique Caetano ${ }^{3}$

\begin{abstract}
PEREIRA, B. F.; PITOL, D. L. \& CAETANO, F. H. An ultrastructural approach for gill responses after pollutants exposure. Int. J. Morphol., 37(1):159-166, 2019.

SUMMARY: Morphological and physiological responses of gills exposed to environmental contaminants are widely described in the literature. Among the primary findings are the lamellar fusion, hyperplasia, aneurysms, proliferation of mitochondria-rich cells and mucous cells. This work has as main objectives, to show the main changes caused by a polluted lake in gills, and understand how each gill's cell type responds to pollutants' exposure. To those individuals of the species, Astyanax altiparanae were exposed to water from an urban lake, which receives such contaminants from various sources. The gills were analyzed under a TEM. Our results showed that prior to these changes, commonly found, only the mucous cells did not show structural changes. Among the main results, we observed the emergence of Rodlet cells in the group exposed to contaminants, as well as severe damage to the mitochondria-rich cells. The latter result was extremely relevant for demonstrating that the proliferation of this cell type, widely described as an alternative ionic regulation, may in some cases be completely inefficient because structurally these cells are no longer able to perform their basic metabolic functions.
\end{abstract}

KEY WORDS: Ultrastructure; Astyanax; Gill; Water pollution.

\section{INTRODUCTION}

Water is essential to maintain vital functions in human beings. As a result of the increasing population growth and consequent rising of water consumption, preserving this resource and conserving its quality have become important issues (Biagini et al., 2009). Aquatic ecosystems are the final destination of industrial, residential and agricultural effluents that could affect water quality (Souza \& Fontanetti). Domestic and industrial residues are in fact the main water contaminants (Calxton et al., 1998 apud Ramesh \& Nagarajan, 2013; White \& Rasmussen, 1998 apud Ramesh \& Nagarajan, 2013), and sewage is one of the main compounds responsible for water quality deterioration in developing countries (Biagini et al.).

Contamination of aquatic resources is currently of great public health concern (Maria et al., 2003 apud Biagini et al.), once that direct or in damage to organisms (Biagini et al.). One form of indirect consumption of water is through consumption of fish, which are commonly used as biomarkers of aquatic ecosystems due to their important role on the food chain and direct and indirect bioaccumulation of toxic substances through ingestion of dissolved compounds or previously contaminated prey (Ramesh \& Agarajan).

According to Harshbarger \& Clark (1990), fish are an optimal test organism for monitoring water quality, especially small aquarium fish that can easily be maintained in the laboratory and can be exposed to toxic substances similarly to other superior vertebrates. After all, these organisms can be used to evaluate contamination potentials even to humans (Biagini et al.).

Gills are the first organs to have contact with contaminants in the water. Due to their large surface, small blood/water diffusion distance (Fernandes et al., 2013) and external position and, therefore are quite vulnerable to water pollutants, being considered an efficient indicator of water quality and contamination level (Barja-Fernández et al., 2013).

\footnotetext{
${ }^{1}$ Federal University of São Paulo (UNIFESP) - Diadema, Brazil.

${ }^{2}$ Faculdade de Odontologia de Ribeirão Preto, FORP/USP, Ribeirão Preto, Brazil.

${ }^{3}$ Universidade Estadual Paulista "Júlio de Mesquita Filho"-UNESP Campus de Rio Claro, São Paulo, Brazil.
} 
Generally, gills respond rapidly to various chemical agents to overcome physiological stress or injuries that can produce negative effects on the general function of gills, increasing fish susceptibility to toxicants and lead to death (Fernandes et al.). Hyperplasia, lamellar fusion and hypertrophy of pavement cells are some modifications that help prevent chemicals from reaching the bloodstream (Fernandes et al.).

Moreover, gills perform numerous functions, such as respiration, osmoregulation, excretion of nitrogenous residues and acid-base balance, so that functional impairment of the organ can damage fish health (Barja-Fernández et al.).

For the reasons cited above the present study aimed to identify alterations on the fine structure of different cellular types of gills from a neotropical fish species Astyanax altirapanae after exposure to water from a contaminated urban lake, and understand if the histological responses to pollutants are really efficient.

\section{MATERIAL AND METHOD}

For this study, 40 juvenile individuals of Astyanax altiparanae donated by CEPTA - Instituto Chico Mendes (Pirassununga, SP) were divided into two groups of 20: a control group kept in water from an artesian well at UNESP - Campus de Rio Claro - São Paulo State and a group exposed to water from an urban lake (Lago Azul - Rio Claro, SP, Brazil) which receives residues from residencies and small industries. Oxygen levels and temperature were controlled throughout the experiment and kept identical for all groups, this lake is contaminated and causes histopathological damage in fish gills as reported by Torres et al. (2010) and Pereira et al. (2012).

Samples were obtained twice, once after 1 month of experiment and once after 5 months of the experiment. Four individuals were sampled each time. Before sacrifice, they were anaesthetized with a benzocaine solution $(0.1 \mathrm{~g}$ of benzocaine on $1 \mathrm{~mL}$ of ethyl alcohol and $100 \mathrm{~mL}$ of deionized water).

For ultrastructural analyses, the samples were processed according to Reynolds (1963). Gill fragments were fixed with $2.5 \%$ glutaraldehyde in sodium cacodylate buffer (0.1 M, pH 7.2) for 2 hours, refrigerated. Samples were then, washed twice in sodium cacodylate buffer for 15 minutes and post-fixed in $1 \%$ osmium tetroxide. Another two washes with buffer were performed before uranyl acetate staining (1\% uranyl acetate in $10 \%$ ethanol for 8 hours). At last, the gills were dehydrated in ethanol (70\% to $100 \%)$, embedded in
Epon-Araldite resin and acetone (1:1) for 24 hours and finally, embedded in pure Epon-Araldite resin polymerized at $60{ }^{\circ} \mathrm{C}$ for 72 hours in the incubator. Resin blocks were sectioned with a Porter Blum ultramicrotome, sections were mounted on copper meshes and stained with uranyl acetate for 45 minutes and lead citrate for 15 minutes. Sections were analyzed and photographed on a Philips CM100 transmission electron microscope at UNESP - Rio Claro - Departamento de Biologia - Instituto de Biociências).

All experimental procedures were repeated 3 times to confirm the results.

\section{RESULTS}

Gills were composed of four types of cells:

1. Pavement cells, which usually possess an elongated nucleus (Fig. 1A) and micro ridges, mostly observed in epithelial cells from primary lamellae (Fig. 1C). They also exhibit elongated mitochondria with few crests, Golgi apparatus and large amounts of the smooth endoplasmic reticulum, ribosomes and free polyribosomes (Fig. 1B).

2. Pillar cells, found amongst epithelial cells of secondary lamellae and whose function is to define and maintain a space for erythrocyte traffic (Fig. 1A). They show irregular nucleus and mitochondria similar to the ones in pavement cells, but endoplasmic reticulum or Golgi apparatus is rarely observed.

3. Mucous cells, with basal nucleus and cytoplasm filled with secretory vesicles (Fig. 1D).

4. Mitochondria-rich cells (chloride cells) (Fig. 1E), showing irregular nucleus, cytoplasm filled with elongated mitochondria which possess many crests, large amounts of vesicles and a complex network of the endoplasmic reticulum (Figs. 1F and 2B). When found on primary lamellae, these cells are surrounded by pavement cells and only a small portion of the plasma membrane is exposed to the water and is covered by glycocalyx (Fig. 2A).

Among alterations observed there was an increase in blood cell volume in secondary lamellae (secondary lamellar dilation), characterizing aneurisms along with smaller and free pillar cells that normally should adhere to pavement cells to form a channel (Fig. 2C).

In mitochondria-rich cells, cytoplasm degradation was observed, with disappearance or disorganization of 

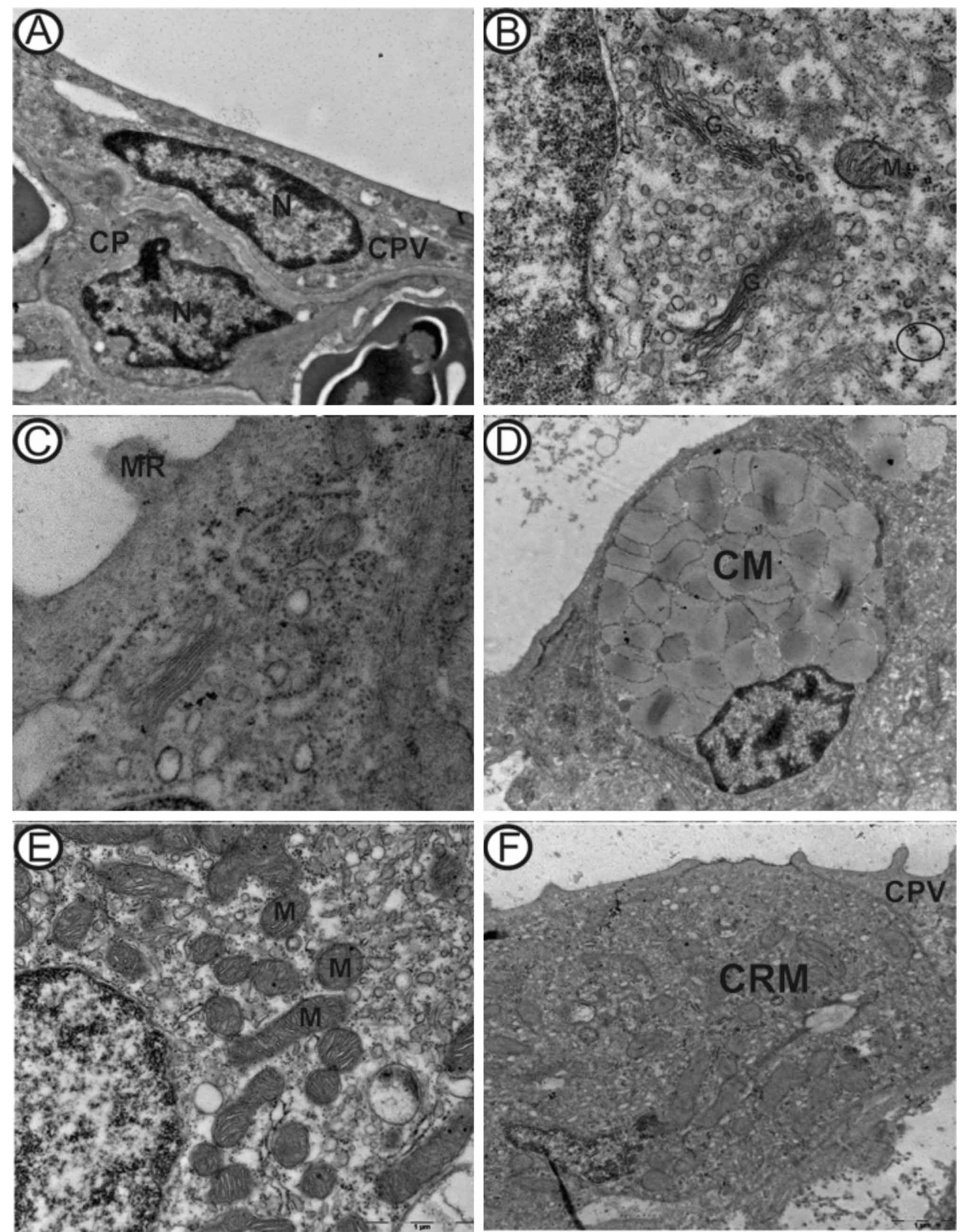

Fig. 1. A. Micrograph of control groups exemplifying pavement cells (CPV) with elongated nucleus (N) and a pillar cell (CP) with irregular nucleus positioned between the pavement cells, forming the space for erythrocytes to pass through. B. Cytoplasm of a control pavement cell showing the Golgi apparatus $(\mathrm{G})$, round mitochondria $(\mathrm{M})$ and free ribosomes (detail). C. Microrigde (MR) in pavement cell from the control group. D. Mucous cell from the control group (CM), notice the basal nucleus and apical region filled by secretion vesicles. E. Elongated mitochondria characteristic of mitochondria-rich cells from the control group. F. Mitochondria-rich cell (CRM) from the control group, notice that only a small region of the plasma membrane is exposed. 

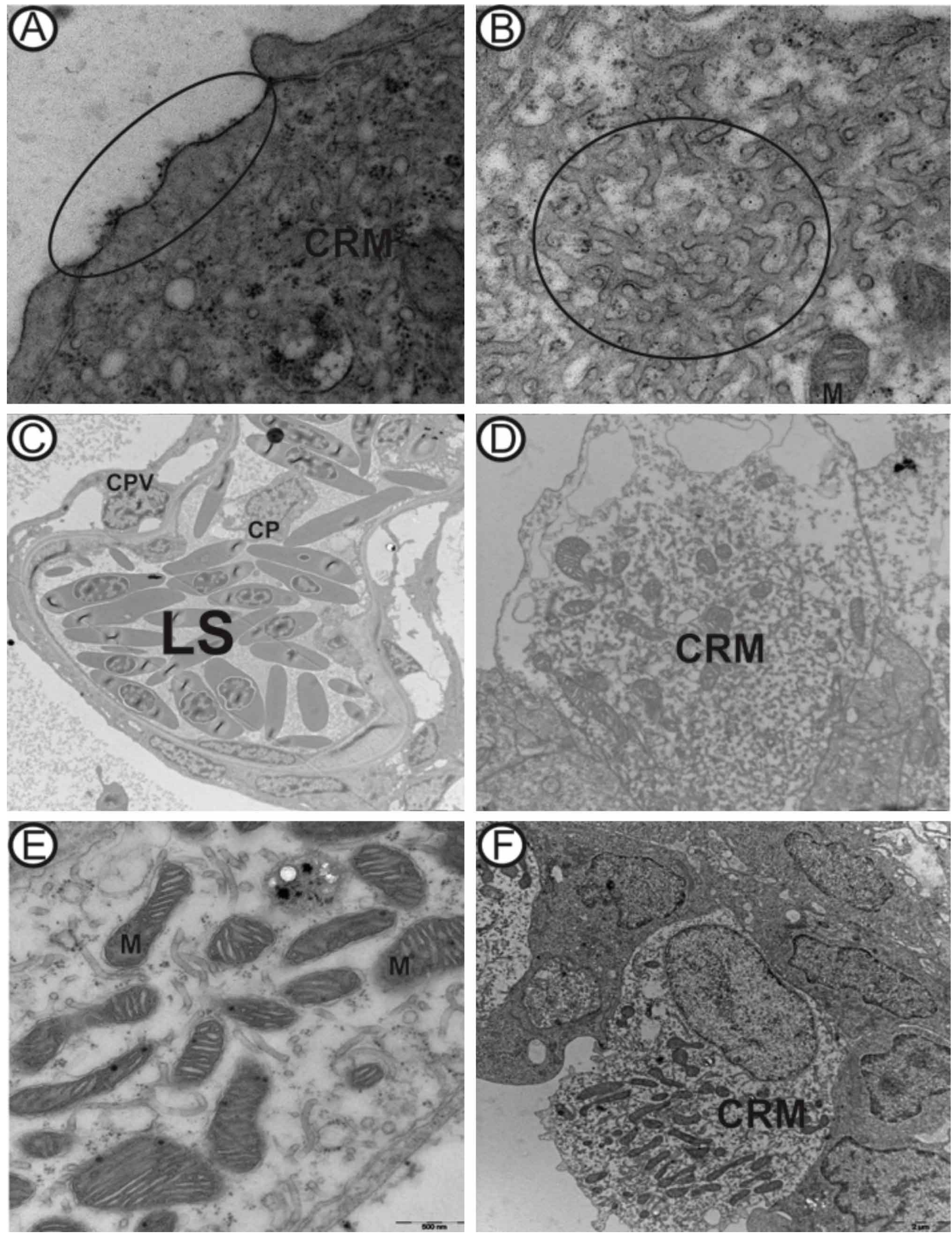

Fig. 2. A. Mitochondria-rich cell (CRM), notice the highlighted area, the plasma membrane exposed to the environment, covered by a glycocalix layer. B: Mitochondria-rich cell cytoplasm, notice the highlighted area, a complex web formed by the endoplasmic reticulum. C. Aneurism in secondary lamella. Observe pillar cells (CP) detached and pavement cells partially detached. D. Mitochondria-rich cell after exposure to pollutants, observe cytoplasmic degradation and vacuolization. E. Mitochondria-rich cell after exposure to pollutants, observe rigde and intermembrane space dilation (M). F. Mitochondriarich cell after exposure to pollutants, observe increased exposed plasma membrane area. 

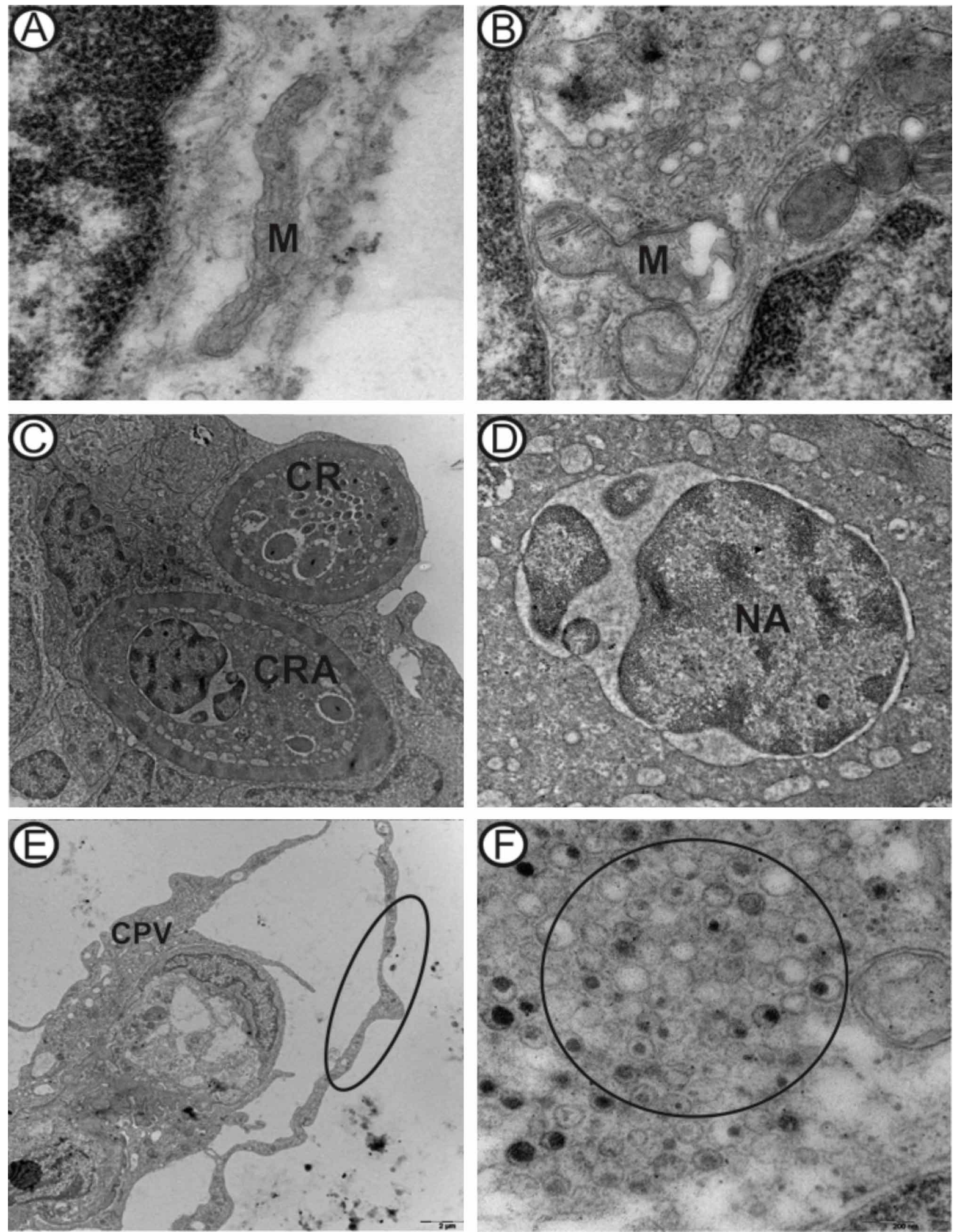

Fig. 3. A. Mitochondria (M) in a pavement cell exposed to urban lake water. B. Degenerated mitochondria after exposure to pollutant. C. Rodlet cell nucleus (CR) and apoptotic rodlet cell (CRA), observe apoptotic body formation. D. Pavement cell nucleus in apoptotic process (NA), observe fragmentation of genetic material. E: Pavement cell (CPV) in secondary lamella after exposure to urban lake water, observe reduction and detachment of cytoplasm (highlighted area). F: Peroxisome aggregation in pavement cell after exposure to urban lake water. 
endoplasmic reticulum network and mitochondrial degradation evidenced by mitochondrial crest degeneration and dilation of intermembrane space (Figs. 2D and 2E). Generally, mitochondria-rich cells lose glycocalyx after exposure to pollutants, whereas contact area of the plasma membrane with the exterior increases considerably (Fig. 2F). This event is due apparently to a coordinate loss or derangement of junction complexes that connect pillar cells to pavement cells.

Pavement cells in both primary and secondary lamellae exhibit mitochondrial fusions that generate extremely long mitochondria that occupy almost the entire length of the cell (3A). Even when mitochondria are fused together the same patterns of inter membrane space dilation and crest degradation are identified (Fig. 3B).

Rodlet cells were found in primary lamellae, which in some cases possessed degenerate cytoplasm and organelles, cytoplasm and nuclear fragmentation that form apoptotic corps (Figs. 3C and 3D). Some peculiarities found in secondary lamellae were a reduction of cytoplasm volume in some pavement cells, in which no organelles can be identified, cells partially detached from the lamella and, in extreme cases, cells completely detached from the tissue (Fig. 3E). Peroxisome groups also accumulated in pavement cells after exposure to pollutants (Fig. 3F).

\section{DISCUSSION}

Normal morphological features of Prochilodus scrofa gills comprise a stratified epithelium in filaments between lamellae, along with mitochondria-rich cells and mucous cells. Lamellar epithelia consists of one superficial layers of pavement cells and one layer of undifferentiated cells aligned to the basal lamina that wraps around pillar cells and whose projections form vascular channels. Our control data corroborate such statements for both species. Ultrastructural description of cellular structures and organelle frequency of all four cellular types presented in our study are also compatible with descriptions by Wilson \& Laurent (2002) for freshwater fishes.

Gills are considered to be the primary target-organ of all aquatic pollutants due to an extensive contact surface and reduced distance between internal and external environments (Cerqueira \& Fernandes, 2002). Toxic effects of metals and other types of contaminants in morphology and physiology of gills have been investigated by several authors during acute or chronic exposure (Cerqueira \& Fernandes).
These morphological effects, even due to low concentrations of metals, can functionally affect fundamental processes such as osmoregulation and antioxidant defense in gills (Puerto et al., 2010). Although most of the brachial lesions caused by experimental dosages of contaminants occur on the epithelium, potential toxic effects can indirectly affect other organs in the case of agents with systemic toxicity (Barja-Fernández et al.).

Abdel-Moneim et al. (2012) classified main histological alterations observed in fish gills captured in metal contaminated Egyptian rivers into three reaction patterns: (1) circulatory disturbs, which include aneurisms, lamellar blood congestion and hemorrhage; (2) proliferative cellular responses, which include hyperplasia, hypertrophy and fusion; (3) osmoregulatory responses, which include epithelial lifting, dilation and interstitial edema. Our results indicate that both contaminants cause the three types of alterations described above, often simultaneously in the same portion of tissue as is the case of aneurisms and epithelial lifting.

Several authors have reported alterations on the gill vascular system, such as congestion of erythrocytes, aneurisms and necrosis exposed to lead, and in some cases, its frequency grows concomitantly to lead concentration (Martinez et al., 2004). Non-metallic contaminants such as $2,2^{\prime}, 4,4^{\prime}$ tetrabromodiphenyl ether (BDE-47) also affect the gill vascular system of brills, inducing blood congestion, indicated by enlargement of the lamellar vascular channel and accumulation of blood cells (Barja-Fernández et al.). These alterations can be related to rupture of pillar cells, which induces loss of vascular integrity and enhance blood flow inside the lamella (Barja-Fernández et al.).

Blood congestion due to contaminated environments, sometimes by organophosphates (Fanta et al., 2003; BarjaFernández et al.) is considered a severe injury of difficult recovery, when compared to epithelial alterations and probably causes damage to functions associated to other gill tissues (BarjaFernández et al.;).

Cellular responses such as epithelial filament cell proliferation, lamellar pavement cell hypertrophy have been observed by several authors (Fishelson, 1980; Martinez et al., 2004; Barja-Fernández et al.;) in fish exposed to metallic and non-metallic contaminants. These types of lesion can be unilateral (affect only one surface of the lamellar epithelium) or bilateral (affect both surfaces) (Barja-Fernández et al.) and its frequency varies according to the type of contaminant and dosage. In some cases alteration such as hyperplasia has only been observed in high doses of toxicant - for example, P. lineatus specimens exposed to lead - and occasionally lead to fusion of adjacent lamellae and even of lamellae from adjacent filaments (Martinez et al.). 
Our experiments showed bilateral modification. However, we considered ultrastructural modifications to be more severe than proliferation or cellular hyperplasia. In such case mitochondrial degeneration in epithelial cells, degeneration of other cytoplasmic organelles and peroxisome proliferation, which is involved in detoxing processes. The results demonstrate that even with cellular proliferation, these cells that would serve as a barrier against pollutants are greatly affected by combinations of contaminants and will be rapidly eliminated, once that mitochondrial damage triggers apoptotic processes.

Mitochondria-rich cells, which are absorption sites for $\mathrm{Na}+\mathrm{Cl}-\mathrm{e} \mathrm{Ca} 2+$ in freshwater fish (Fernandes et al.) can also suffer proliferative changes and are characterized by numerous mitochondria and a ATPase $\mathrm{Na}+\mathrm{K}+$-rich tubular membrane system (DANG et al., 2000 apud Fernandes et al.). Apical morphology of mitochondria-rich cells varies amongst freshwater species and superficial area correlates to the $\mathrm{Na}+\mathrm{Cl}-$ exchange system and fractional area of mitochondria-rich cells (Fernandes et al.).

Despite hyperplasia being classified as a proliferative alteration, changes in mitochondria-rich cells density and apical surface indicate ionic disturbances (Moron et al., 2003; Fernandes et al.). Aquatic contaminants can cause ionic imbalance by enhancing loss of diffusion ions and/or reducing mitochondria-rich cell activity due to toxic action (Fernandes et al.).

Other than that, proliferative responses in mitochondria-rich cells caused by exposure to metals are considered compensatory responses to maintain ionic balance but their turnover results in recently emerged augmented subpopulations, apoptotic and necrotic cells with low ATPase $\mathrm{Na}+/ \mathrm{K}+$ activity and ionic imbalance (Cerqueira \& Fernandes).

The present study demonstrates that mitochondriarich cell hyperplasia was accompanied by mitochondrial degeneration and endoplasmic reticulum web aside from enhancement of the contact surface. These internal modifications indicate that even when attempting to regulate ionic imbalance generated by pollutants, the cells are probably not capable of functioning anymore. Moreover, loss of glycocalyx, a selective filter can also lead to undue the entry of substances in the organism.

Low doses of lead provoked lamellar epithelial lifting in gills of $P$. lineatus (Martinez et al.) which was probably a consequence of severe edema formation between the vascular lamellar channel and the site of the lifting (BarjaFernández et al.). Other alterations also recorded by literature are those on the membrane ridge. Normally these ridges occur at the membrane periphery parallel to adjacent cells cellular junctions, while close to the center they diverge and form a structure similar to a labyrinth, specifically shaped in several species (Fishelson). Some ridge from the superficial cells project over mitochondria-rich cell openings that based on electronic microscopy images is called microvilli

(Fishelson). In P. scrofa specimens exposed to copper micro ridge of epithelial pavement cells from the filament change shape, reduce in number and the pattern of the cellular surface, once composed by elongated forms becomes nearly smooth. Also mitochondria-rich cell surface augments after exposure to copper.

Normally neighboring cells of the pavement epithelial layer are connected amongst themselves and to basal cells by occlusive junctions and desmosomes seem to behave differently in freshwater and marine fish (Fishelson). Gills of fish adapted to marine environments have looser junctions, many opened, and form spaces between epithelial cells (Fishelson).

Epithelial lifting and micro ridge loss are probably due to cytoskeleton damage, once that cytoplasmic degeneration was accompanied by cellular deformation and loss of cellular junctions, which are directly connected to cytoskeleton filaments.

A special type of mucous cell, rodlet cells show similar ultrastructure in several teleost species and their developmental stages are identified based on capsule thickness and chromatin differences (Procópio et al., 2011). Rodlet cells are enveloped by a fibrillar thick capsule, possess cytoplasmic granules described as club-shaped pockets that contain a center of highly electron-dense material and an electron-lucid periphery (Procópio et al.). Several studies evaluate rodlet cell occurrence as a biomarker for environmental impact in teleosts exposed to contaminants (Procópio et al.).

Only fish exposed to contaminated group in our study showed Rodlet cells and in some cases they were apoptotic. This result indicates that there cells can truly be considered bioindicators.

\section{ACKNOWLEDGMENTS}

The authors are thankful to FAPESP, process number: 2009/17118-9, for financial support and to ICMBio/CEPTA - Institute Chico Mendes for providing the specimens used in this experiment. 
PEREIRA, B. F.; PITOL, D. L. \& CAETANO, F. H. Un enfoque ultraestructural de las respuestas branquiales después de la exposición a contaminantes Int. J. Morphol., 37(1):159-166, 2019.

RESUMEN: Las respuestas morfológicas y fisiológicas de las branquias expuestas a contaminantes ambientales se describen ampliamente en la literatura. Entre los hallazgos principales se encuentran la fusión laminar, la hiperplasia, los aneurismas, la proliferación de células ricas en mitocondrias y las células mucosas. Este trabajo tiene como objetivo principal, mostrar los principales cambios en las branquias, causados por un lago contaminado y comprender cómo responde el tipo de célula de las branquias a la exposición de los contaminantes. Individuos de la especie Astyanax altiparanae fueron expuestos al agua de un lago urbano, receptor de contaminantes de diversas fuentes. Las branquias se analizaron bajo un TEM. Nuestros resultados mostraron que antes de estos cambios, comúnmente encontrados, solo las células mucosas no mostraban cambios estructurales. Entre los resultados principales, observamos la aparición de células Rodlet en el grupo expuesto a contaminantes, así como el daño severo a las células ricas en mitocondrias. Este último resultado fue extremadamente relevante para demostrar que la proliferación de este tipo de células, ampliamente descrito como una regulación iónica alternativa, en algunos casos puede ser completamente ineficiente porque estructuralmente estas células ya no son capaces de realizar sus funciones metabólicas básicas.

PALABRAS CLAVE: Ultraestructura; Astyanax; Branquias; Contaminación del agua.

\section{REFERENCES}

Abdel-Moneim, A. M.; El-Saad, A. M.; Hussein, H. K. \& Dekinesh, S. I. Gill oxidative stress and histopathological biomarkers of pollution impacts in Nile tilapia from Lake Mariut and Lake Edku, Egypt. $J$. Aquat. Anim. Health, 24(3):148-60, 2012.

Barja-Fernández, S.; Míguez, J. M. \& Álvarez-Otero, R. Histopathological effects of 2,2',4,4'-tetrabromodiphenyl ether (BDE-47) in the gills, intestine and liver of turbot (Psetta maxima). Ecotoxicol. Environ. Saf., 95:60-8, 2013.

Biagini, F. R.; de Oliveira David, J. A. \& Fontanetti, C. S. The use of histological, histochemical and ultramorphological techniques to detect gill alterations in Oreochromis niloticus reared in treated polluted waters. Micron, 40(8):839-44, 2009.

Cerqueira, C. C. \& Fernandes, M. N. Gill tissue recovery after copper exposure and blood parameter responses in the tropical fish Prochilodus scrofa. Ecotoxicol. Environ. Saf., 52(2):83-91, 2002.

Fernandes, M. N.; Paulino, M. G.; Sakuragui, M. M.; Ramos, C. A.; Pereira, C. D. \& Sadauskas-Henrique, H. Organochlorines and metals induce changes in the mitochondria-rich cells of fish gills: an integrative field study involving chemical, biochemical and morphological analyses. Aquat. Toxicol., 126:180-90, 2013.

Fishelson, L. Scanning and transmission electron microscopy of squamose gill filament epithelium from fresh- and seawater adapted Tilapia. Environ. Biol. Fish., 5(2):161-5, 1980.

Martinez, C. B.; Nagae, M. Y.; Zaia, C. T. \& Zaia, D. A. Acute morphological and physiological effects of lead in the neotropical fish Prochilodus lineatus. Braz. J. Biol., 64(4):797-807, 2004.
Pereira B. F.; da Silva Alves, R. M.; Pitol, D. L.; Senhorini, J. A.; de Alcântara Rocha, R. C. G.; Caetano, F. H. Morphological gill analysis of fish species Prochilodus lineatus after exposure to pollutants. J. Environ. Anal. Toxicol., 2(3):1000130, 2012.

Procópio, M. S.; Ribeiro, H. J.; Rizzo, E.; Sato, Y. \& Corrêa Junior, J. D. Rodlet Cell as Environmental Biomarker in Gill of Curimba (Prochilodus Argenteus): Assessment of Gender Influence by Light and Electron Microscopy. In: Anais do XXIII Congresso da Sociedade Brasileira de Microscopia e Microanálise. Búzios, Sociedade Brasileira de Microscopia e Microanálise, 2011.

Puerto, M.; Prieto, A. I.; Jos, A.; Moreno, I.; Moyano, R.; Blanco, A. \& Cameán, A. M. Dietary N-Acetylcysteine (NAC) prevents histopathological changes in tilapias (Oreochromis niloticus) exposed to a microcystin-producing cyanobacterial water bloom. Aquaculture, 306(1-4):35-48, 2010.

Ramesh, F. \& Nagarajan, K. Evaluation of DNA damage of the fish Clarias batrachus exposed to Sago effluent using comet assay. Eur. Int. J. Sci. Technol., 2(3):12-6, 2013.

Souza, T. S. \& Fontanetti, C. S. DNA damage of erythrocytes of fish Oreochromis niloticus (Perciformes, Cichlidae), after acute exposure to river water receiving affluent from an oil refinery. J. Braz. Soc. Ecotoxicol., 7(2):17-22, 2012.

Torres, R. G. A.; González, S. P. \& Peña, S. E. Anatomical, Histological and Ultraestructural Description of the Gills and Liver of the Tilapia (Oreochromis niloticus). Int. J. Morphol., 28(3):703-12, 2010.

Wilson, J. M. \& Laurent, P. Fish gill morphology: inside out. J. Exp. Zool., 293(3):192-213, 2002.

\author{
Corresponding author: \\ Bruno Fiorelini Pereira \\ Universidade Federal do Oeste da Bahia \\ Barreiras - BA \\ BRAZIL
}

Email: brunofp22@hotmail.com

Received: 30-06-2018

Accepted: 31-08-2018 